Clemencia Merval

\title{
Don Enrique Molina
}

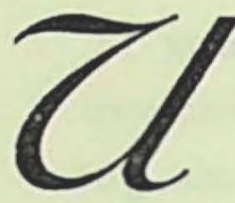

NA vez que en la dura piedra del Sur posó su cabeza sagrada, fue tocado por el sueño de Jacob, a la hora del alba.

$Y$ al despertar, sintió que existia, para reconstituir esa Escala de los Angeles; para suscitar la exaltación divina de la Idea, su esencia y su voluntad hecha carne. Tras el rasgo indeleble de su sombra, marcharán los nacidos y por nacer. "Por el libre desarrollo del Espiritu", hasta cuando no esté, hablaremos de El. En suave crepitar, su llama crece, alimentada en la raíz de su destino. Un arcángel en él se perenniza como su lema, en bronces esculpido. 